\title{
KOMUNIKASI BUDAYA KESENIAN TARI KELING GUNO JOYO \\ DI DESA SINGGAHAN KECAMATAN PULUNG \\ KABUPATEN PONOROGO
}

\author{
Tsalits Maratun Nafiah
}

Universitas Islam Negeri Sunan Ampel, Surabaya

nafiah@gmail.com

\section{Article Info}

Received 1 Agustus 2019

Accepted 5 September 2019

Published 5 Oktober 2019

\section{Keyword:}

Komunikasi Budaya, Kesenian, Tari Keling Guno Joyo.

\section{Abstract}

The art of Keling Guno Joyo Dance is one of the regional dances that still exists and is developed by local residents. This article discusses how cultural communication is displayed in the Keling Guno Joyo Dance art at Dukuh Mojo, Singgahan Village, Pulung District, Ponorogo Regency. This research uses a qualitative-descriptive approach. The research data were analyzed by using Miles and Huberman's descriptive analysis model based on the theory of perception. The result of this research is that cultural communication in the performance of the Keling Guno Joyo Dance is carried out by means of verbal and non-verbal communication, namely through candra, tembang, and rivet songs, and gamelan musical instruments that accompany the dance. In the dance performance, there is a message that is conveyed so that the art of Keling Dance can be used as a traditional communication medium.

Kesenian Tari Keling Guno Joyo merupakan salah satu tari daerah yang hingga saat ini masih eksis dikembangkan oleh warga setempat. Artikel ini membahas tentang bagaimana komunikasi budaya yang ditampilkan dalam kesenian Tari Keling Guno Joyo di Dukuh Mojo Desa Singgahan, Kecamatan Pulung, Kabupaten Ponorogo. Penelitian ini menggunakan pendekatan kualitatif-deskriptif. Data penelitian dianalisis dengan model analisis deskriptif Miles dan Huberman berdasarkan teori persepsi. Hasil penelitian ini adalah komunikasi budaya dalam pementasan kesenian Tari Keling Guno Joyo dilakukan dengan cara komunikasi verbal dan non-verbal, yakni melalui candra, tembang, dan nyanyian-nyanyian keling, dan alat musik gamelan yang mengiringi tarian. Dalam pementasan tari terdapat pesan yang disampaikan sehingga kesenian Tari Keling dapat digunakan sebagai media komunikasi tradisional. 


\section{Pendahuluan}

Indonesia merupakan negara yang kaya akan suku dan budaya. Beragamnya budaya yang ada di Indonesia merupakan wujud warisan Indonesia sebagai negara Bhinneka Tunggal Ika yang berarti meskipun berbeda-beda tetapi tetap satu jua. Dari semboyan tersebut masyarakat Indonesia dapat memilih budaya maupun tradisi di lingkungan hidup suatu masyarakat. Kesenian adalah unsur universal yang menjadi cerminan dari peradaban manusia pendukungnya. Hampir di setiap daerah memiliki keunikan warisan budaya dan kesenian yang berbeda antara satu suku dengan suku lainnya. Dengan begitu sering adanya pertunjukan seni dan budaya lokal dari masing-masing daerah akan mendorong semangat patriotisme untuk lebih kreatif dalam meningkatkan eksistensi budaya di Indonesia.

Kesenian dan manusia pada dasarnya tidak dapat dipisahkan. Kesenian adalah suatu perwujudan perasaan seseorang yang tidak bebas dari masyarakat dan kebudayaan seseorang dibesarkan. ${ }^{1}$ Sejak awal sejarahnya dimana sebelum mengenal tulisan, seni sudah menjadi bagian dalam kehidupan manusia. Kesenian sebagai salah satu unsur kebudayaan merupakan ungkapan kreatifitas manusia yang memiliki nilai keluhuran dan keindahan. Kesenian tradisional sebagai pertunjukan selalu dilestarikan oleh masyarakat, sehingga kesenian itu berkembang. ${ }^{2}$

Indonesia yang memiliki ragam seni maupun budaya yang menggali dan

$\begin{array}{crr}\text { Koentjaningrat, } & \text { Pengantar } & \text { Ilmu } \\ \text { Antropologi, (Jakarta: Aksara Baru, 1985), } & 204\end{array}$ mengembangkan serta melestarikan budaya yang telah diturunkan oleh para leluhurnya. Usaha pelestarian warisan itu memiliki manfaat yang cukup penting bagi kelangsungan hidup seni budaya itu sendiri. Dalam kesenian terdapat lambang yang akan menjadi ciri khas kelompok masyarakat. Pengembangan yang selaras dengan usaha pengembangan kebudayaan nasional dituntut oleh kedudukan kesenian, karena kebudayaan nasional merupakan suatu kesatuan besar yang terdiri dari berbagai macam kebudayaan, contohnya kesenian tradisional.

Ciri khas kerakyatan yang melekat dalam suatu kesenian menunjukkan bahwa kesenian berasal dari suatu daerah asalnya. Kesenian sangat erat kaitannya dengan kajian komunikasi, karena dalam kehidupan berbudaya juga perlu memahami tentang konsep komunikasi budaya. Dalam sebuah pertunjukan, kesenian memiliki sifat yang komunikatif sehingga pesan dan tujuannya mudah diterima dan difahami oleh masyarakat pedesaan.

Agama Islam juga tidak pernah melarang suatu kaum melestarikan kebudayaan atau kesenian, jika keduanya memiliki nilai manfaat yang lebih tinggi dari mudharatnya. Misalnya melestarikan budaya dengan tujuan menyebarkan agama islam atau hanya sekededar hiburan untuk masyarakat. Ulama Syafi'iyah yang dijelaskan oleh Imam Al-Ghazali dalam kitabnya Ihya Ulumuddin yang menjelaskan bahwa menyanyi, menari, dan memukul rebana dengan memainkan

2 Dick Hartoko, Manusia dan Seni, (Yogyakarta: Kanisius, 1984), 21. 
senjata-senjata perang pada hari raya hukumnya boleh (mubah) karena hari raya merupakan hari bahagia.

Pertunjukan tradisional yang berisi pesan tidak hanya pertunjukan yang mengandung unsur drama, seperti Wayang Golek, Wayang Kulit, dan Wayang Orang, namun masih banyak kesenian lain yang berisi pesan dan dijadikan sebagai media komunikasi tradisional, seperti keling, badui, shalawatan, dan lain-lain. Yang sangat menonjol nilai religinya dalam seni tradisional adalah shalawatan.

Ponorogo terletak di Jawa Timur bagian barat berbatasan langsung dengan Wonogoiri Tawa Tengah tepatnya $220 \mathrm{~km}$ arah barat daya dari ibu kota provinsi Jawa Timur. Dengan jumlah penduduk di Kabupaten Ponorogo adalah 986.224 jiwa. ${ }^{3}$ Kabupaten Ponorogo terdiri dari 21 kecamatan, 279 desa serta 26 kelurahan. Ponorogo sangat kaya akan keberagaman seni budaya, pariwisata, serta kuliner. Mulai dari Telaga Ngebel, air terjun pletuk, tanah goyang, Coban lawe, gunung bedes, air terjun toyomerto serta masih banyak tempat wisata lain yang mampu menarik wisatawan berkunjung ke kabupaten Ponorogo. Dari sektor perekonomian, Ponorogo bisa dikatakan sebagai kabupaten yang berkembang, banyak usaha kecil menengah serta pertokoan sejenis swalayan mulai berkembang di kabupaten Ponorogo.

Dalam sektor kuliner, Ponorogo memiliki makanan khas yang paling terkenal yaitu sate Ponorogo. Dari dunia pendidikan Ponorogo disebut sebagai kota santri. Hal ini di dukung dengan banyaknya pesantren, salah satunya adalah Pondok Pesantren Modern Darussalam Gontor. Yang paling menonjol dari kota Ponorogo adalah seni budayanya. Ponorogo merupakan daerah asal kesenian Reyog. Sudah bukan hal asing lagi bagi masyarakat Jawa Timur maupun nasional ketika mendengar kata Ponorogo pasti yang terbesit adalah kota REYOG.

Selain Reyog Ponorogo juga memiliki kesenian lain yang belum terlalu dikenal antara lain yakni kesenian Jaranan Thik, Tari Keling, Gajah-Gajahan, dan masih banyak lagi. Kesenian-kesenian tersebut memiliki keunikan dan daya tarik tersendiri, seperti kesenian Tari Keling. Tari Keling merupakan kesenian tradisional yang diperkenalkan oleh nenek moyang masyarakat Dusun Mojo Desa Singgahan Kecamatan Pulung Kabupaten Ponorogo. Kesenian Keling telah lama hidup dan menyatu dengan kehidupan masyarakat dukuh Mojo. Dari segi kostum kesenian Tari Keling menunjukkan kesederhanaan, suara musik tradisional pengiringnya akan menambah sakral suasana saat pementasan. Letak Dusun Mojo disebelah Timur dari pusat Kabupaten Ponorogo. Masyarakat Dusun Mojo memiliki ciri khas masyarakat yang masih kental dengan kekeluargaannya. Siikap anggah ungguh dan gotong-royong masih erat dalam kehidupan sehari-hari.

Paguyuban kesenian keling berdiri pada tahun 1942 yang pada mulanya

\footnotetext{
Dokumentasi Statistik Kabupaten, "Kabupaten Ponorogo dalam Angka, (Ponorogo: DSK, 2012), 1.
} 
diketuai oleh Khasan Ngali. Hanya dengan menggunakan bekal peralatan sederhana masyarakat berhasil membangkitkan kesenian Tari Keling yang sempat tenggelam dari keseharian masyarakat. Kurangnya perhatian dari pihak-pihak terkait, membuat kesenian kesenian Tari Keling adalah satu-satunya. Walaupun dahulu ada daerah lain yang mencoba ikut membuat Tari Keling, namun mereka tidak bisa bertahan lama dikarenakan nilai filosofis yang terkandung dalam penyajiannya. Hal tersebut menjadikan semangat masyarakat Dusun Mojo untuk terus melestarikan kesenian Tari Keling. Keinginan masyarakat untuk menjaga dan melestarikan kesenian Tari Keling adalah dengan membuat paguyuban. Paguyuban tersebut saat ini bernama "Guno Joyo" yang berada di Dusun Mojo Desa Singgahan Kecamatan Pulung Kabupaten Ponorogo. Menurut sesepuh kesenian keling yaitu mbah Wiryono kesenian ini merupakan satu-satunya di Indonesia yaitu berada d Dukuh Mojo. ${ }^{4}$

Kesenian Keling sebagai kesenian tradisional merupakan suatu bentuk kesenian yang memiliki nilai gerak tertentu yang terikat dengan pola kehidupan masyarakat dukuh Mojo. Kesenian ini telah berkembang dari masa ke masa dan mengandung nilai religius, sebagaimana bahwa kesenian tradisional adalah kesenian yang hubungannya sangat erat dengan masyarakatnya. Kesenian Keling telah menjadi daya tarik bagi masyarakat Ponorogo pada umumnya bahkan masyarakat di luar Ponorogo. Pertunjukan

4 Wawancara dengan Mbah Wiryono, pada tanggal 21 Maret 2019. kesenian Keling yang berbentuk arakarakan sangat berbeda dengan pertunjukan Reyog.

Menurut salah satu masyarakat Dusun Mojo Desa Singgahan Kecamatan Pulung Kabupaten Ponorogo yaitu mbah Toinem, keberadaan kesenian Tari Keling mampu memupuk rasa kebersamaan dan kekeluargaan. ${ }^{5}$ Dalam kesenian tari keling terdapat aspek komunikasi budaya yang jarang diketahui oleh penonton atau masyarakat. Kebanyakan masyarakat menyaksikan pertunjukan kesenian hanya untuk hiburan semata tanpa tahu pesan atau akna yang disampaikan melalui kesenian terebut. Hal tersebut menandakan bahwa keberadaan Tari Keling juga dapat mempererat kebersamaan dan kekeluargaan masyarakatnya. Oleh karena itu peneliti akan meneliti Komunikasi Budaya dalam Kesenian Tari Keling Guno Joyo Dusun Mojo Desa Singgahan Kecamatan Pulung Kabupaten Ponorogo.

\section{Kajian Pustaka}

\section{Komunikasi Budaya dalam Kesenian}

Pengertian Komunikasi semakin luas hingga ranah budaya, karena terdapat keterkaitan erat antara unsur-unsur budaya dan komunikasi dalam membangun relasi dan kehidupan bersama. Komunikasi merupakan bentuk-bentuk suara yag dipakai melalui bahasa sehari-hari oleh sebab itu untuk mengerti dan mengkomunikasikan suatu kebenaran harus dipelajari dalam kebudayaan itu sendiri. Harold Laswell mengatakan

5 Wawancara dengan Mbah Toinem, pada tanggal 15 April 2019. 
bahwa cara untuk menjelaskan makna komunikasi adalah menjawab pertanyaan who say what in whice channel to whom with effect (siapa yang mengatakan apa yang dikatakan melalui saluran dengan efek. ${ }^{6}$

Budaya adalah cara manusia berbicara dan berpakaian, makanan yang manusia makan dan cara manusia menyiapkan dan mengkonsumsinya, dewa-dewa yang manusia ciptakan dan cara manusia memujanya, cara manusia membagi waktu dan ruang dan nilai-nilai yang disosialisasikan kepada masyarakat dan semua detail lainnya yang membentuk kehidupan sehari-hari.

Perspektif tentang budaya ini mengimplikasikan bahwa tidak ada budaya yang secara inhern lebih unggul dari budaya yang lainnya dan bahwa kekayaan budaya tidak ada kaitannya sama sekali dengan status ekonomi, budaya sebagai kehidupan sehari-hari merupakan ide yang tetap demokratis. ${ }^{7}$

Budaya adalah sebuah konsep yang membangkitkan minat. Secara formal budaya didefinisikan sebagai tatanan pengetahuan, pengalaman kepercayaan, waktu, peranan, konsep alam semesta, objek-objek materi yang diperoleh sekelompok besar generasi ke generasi melalui usaha individu maupun kelompok. Budaya menampakkan diri dalam polapola bahasa dan dalam bentuk-bentuk kegiatan dan perilaku yang berfungsi

\footnotetext{
${ }^{6}$ Onong Uchjana Effendy, Ilmu Komunikasi, Teori dan Praktek, (Bandung: Remaja Rosda Karya, 2001), 18.

7 James Luil, Media Komunikasi dan Kebudayaan, (Jakarta: Yayasan Ober Indonesia, 1998), 86.
}

sebagai model-model bagi tindakantindakan penyesuaian diri dan gaya komunikasi yang memungkinkan orangorang tinggal dalam suatu masyarakat di suatu lingkungan geografis tertentu pada suatu tingkat perkembangan teknis tertentu dan pada suatu saat tertentu. ${ }^{8}$

Budaya komunikasi dan budaya tidak dapat didpisahkan oleh karena itu budaya tidak hanya menentukan siapa berbicara dengan siapa, tentang apa, dan bagaimana komunikasi berlangsung, tetapi juga turut menentukan orang menjadi pesan, makna yang ia miliki untuk pesan dan kondisikondisinya untuk mengirim, memperhatikan dan menafsirkan pesan. Sebenarnya seluruh pembendaharaan perilaku tergantung pada budaya dimana masyarakat bertempat tinggal dan dibesarkan. Hal inilah yang menandakan bahwa budaya adalah landasan komunikasi, bila budaya beraneka ragam pula praktek model komunikasinya. ${ }^{9}$

Komunikasi Budaya juga dapat diartikanproses kehidupan bermasyarakat dalam kehidupan sehari-hari, yang mana proses pesan dan informasi itu muncul melalui kesamaan dalam menangkap suatu makna dan sandi-sandi yang ada dalam tubuh masyarakat. Untuk komunikasi budaya adalah komunikasi yang terjadi dalam kebudayaan yang sama.

\section{Fungsi Komunikasi Budaya Dalam Kesenian}

8 Dedi Mulyana dan Jalaludin Rahmat, Komunikasi Antar Budaya, (Bandung: Remaja Rosda Karya), 19.

${ }^{9}$ Alo Liliweri, Gatra-Gatra Komunikasi Antar Budaya, (Yogyakarta: Pustaka Belajar, 2001), 20. 
Berdasarkan kerangka yang dikemukakan William I. Gorden fungsi komunikasi ada empat, yaitu ${ }^{10}$ : Pertama, Komunikasi sosial, fungsi komunikasi sebagai komunikasi sosial setidaknya mengisyaratkan bahwa komunikasi penting untuk membangun konsep diri, aktualisasi diri, untuk kelangsungan hidup, untuk memperoleh kebahagiaan, terhindar dari tekanan dan ketegangan, antara lain lewat komunikasi yang menghibur, dan memupuk hubungan dengan orang lain.

Kedua, komunikasi ekspresif, erat kaitannya dengan komunikasi sosial adalah komunikasi ekspresif yang dapat dilakukan baik sendirian ataupun dalam kelompok. Kamunikasi ekspresif tidak otomatis bertujuan mempengaruhi orang lain, namun dapat dilakukan sejauh komunikasi tersebut menjadi instrumen untuk menyampaikan perasaan-perasaan (emosi). Perasaan tersebut dikomunikasikan terutama melalui pesan-pesan nonverbal. Perasaan sayang, peduli, rindu, sedih, bahagia, marah, dan lain-lain dapat disampaikan melalui kata-kata, namun terutama lewat perilaku nonverbal.

Ketiga, komunikasi ritual, erat kaitannya dengan komunikasi ekspresif adalah komunikasi ritual, yang biasanya dilakukan secara kolektif. Suatu komunitas sering melakukan upacara-upacara berlainan sepanjang tahun yang disebut dengan rites of pasage, mulai dari upacara kelahiran, khitan, ulang tahun, pertunangan, siraman, pernikahan (ijab qabul, sungkeman atau memberi hormat kepada orang tua), dalam acara-acara tersebut orang-orang menampilkan perilaku-perilaku simbolik. Mereka yang berpartisipasi dalam bentuk komunikasi ritual tersebut menegaskan kembali komitmen mereka terhadap tradisi keluarga, komunitas, suku, bangsa, negara, ideologi, atau agama mereka.

Keempat, komunikasi intrumental, mempunyai beberapa tujuan umum, yaitu menginformasikan, mengajar, mendorong, mengubah sikap dan keyakinan, dan mengubah perilaku atau menggerakkan tindakan, dan juga menghibur. Jika diringkas maka, kesemua tujuan tersebut dapat disebut membujuk (bersifat persuasif). Komunikasi yang berfungsi memberitahukan atau menerangkan (to inform) mengandung muatan persuasif dalam arti bahwa pembicara menginginkan pendengarnya mempercayai bahwa fakta atau informasi yang disampaikannya akurat dan layak diketahui.

Kebudayaan mempunyai fungsi integratif yang memberikan dasar dan orientasi bagi anggota masyarakatnya sehingga menimbulkan semangat, rasa aman, rasa memiliki, cita rasa sebagai masyarakat itu. Kebudayaan juga menimbulkan tertib damai hidup bermasyarakat dengan adat istiadat, kebatinan dan kesusilaan, angan-angan manusia yang menimbulkan keseluruhan bahasa, kesusastraan dan dalam masyarakat itu akan merasa bahwa ia orang baru atau orang luar yang tidak berbagi pemahaman pengetahuan, cita rasa,

${ }^{10}$ Deddy Mulyana, Ilmu Komunikasi: Suatu Pengantar, (Bandung: Remaja Rosdakarya, 2009), 35. 
semangat, ekspresi, dan apresiasi dengan masyarakat itu. ${ }^{11} \quad$ Fungsi komunikasi dalam kesenian tari keling adalah meberikan enkulturasi dan pendidikan moral kepada setiap masyarakat.

Dengan adanya kesenian tari keling berbagai nilai-nilai pendidikan dan moral ditransmisikan dari seorang kepada orang lain. Nilai-nilai pendidikan dan moral ini mencakup norma-norma agama, sopan santun dan etika, keindahan atau estetika, penampilan diri, penempatan diri dalam masyarakat, hidup dalam kepentingan individu dan kelompok, menghargai orang lain, bertingkah laku baik, dan lain-lain. Komunikasi terjadi timbal-balik antara pemain kesenian tari keling dengan para penontonnya.

Oleh sebab itu kesenian tari keling mampu menciptakan hubungan antar komunikan dan komunikator. Melalui pertunjukan ini terdapat petemuan langsung antara komunikan dan komunikator, dimana komunikator dapat mengungkapkan ide dan gagasannya kepada komunikan melalui pesan dalam kesenian.

\section{Budaya sebagai Identitas Bangsa}

Secara etimologi Budaya atau kebudayaan bersasal dari kata sansekerta, "Budhayah" yang merupakan bentuk jamak dari kata "budhi" yang berarti sebagai hal-hal yang berkaitan dengan budi atau akal. Kemudiam dalam bahasa inggris kebudayaan disebut dengan "culture" yang berasal dari kata latin "coltore” yaitu

11 Sulaiman \& Setya Gumilar, Teori-Teori Kebudayaan, (Bandung: Pustaka Setya, 2013), 50. mengolah dan mengerjakan. Kata culture sendiri juga sering diterjemahkan dalam bahasa indonesia sebagai kulture. ${ }^{12}$

Budaya merupakan identitas bangsa yang harus dijaga, dihormati, dan dilestarikan agar budaya Indonesia tetap ada dan bisa menjadi warisan untuk anak cucu nanti. Budaya yang ada di Indonesia disebut budaya nasional. Indonesia memiliki bahasa daerah terbanyak di dunia. Berdasarkan penelitian The Summer Institute of Linguistic, bahasa daerah di seluruh wilayah nusantara sebanyak 726 . Namun bahasa yang digunakan sebagai bahasa nasional adalah bahasa Indonesia. Dengan adanya keanekaragaman yang ada di Indonesia tersebut, maka dibutuhkan adanya toleransi yang besar sesama masyarakat. ${ }^{13}$

Selain itu Indonesia juga memilik berbagai macam kebudayaan yang populer di dunia, misalnya wayang kulit, seni batik, beraneka jenis seni tari, upacara adat yang dilakukan ketika orang menikah, ketika orang melahirkan, ketika orang wafat, dan aneka macam kebiasaan adat istiadat lainnya juga beranekaragam.

Kesenian daerah yang dimiliki Indonesia pun juga beranekaragam jenisnya, diantaranya fasilitas musik, lagu, tarian dan seni pertunjukan. Contohnya sarana musik gamelan (jawa), media musik calung dan angklung (Jawa Barat), fasilitas musik gambang kromong (Betawi), fasilitas musik kolintang (Minahasa), musik sasando (kupang) dan masih banyak lagi lainnya.

12 Moch. Choirul Arif. Dasar-dasar Kajian Budaya dan Media, (Sidoarjo: UIN Sunan Ampel Press, 2014), 18.

${ }^{13}$ Moch. Choirul Arif. Dasar-dasar, 18. 
Setiap daerah Indonesia ini mempunyai beragam lagu tradisional, seperti lagu bubuy Bulan berasal dari Jawa Barat, Ilir-ilir dan Gambang Suling (Jawa Tengah), Ampar-ampar Pisang (Kalimanatan Selatan), Injit-injit Semut (Jambi), Soleram (Riau) dan lagu-lagu lainnya. Selain itu juga ada beragam jenis tarian dan seni pertunjukan dari beraneka daerah di Nusantara. Indonesia memiliki bangunan berejarah yakni candi-candi yang mempunyai ciri khas budaya dari daerah masing-masing. Contohnya adalah candi Borobudur yang sudah dipercaya menjadi salah satu dari 7 keajaiban dunia.

Tidak hanya itu, nilai-nilai hidup atau norma-norma kehidupan membuat Indonesia menjadi bangsa yang bernilai di mata negara lain. Study membuktikan bahwa banyak turis mancanegara yang mengatakan bahwa orang Indonesia memiliki sikap ramah, murah senyum dan baik. Hal- hal seperti itu dapat membuat Indonesia mendapat nilai plus dimata dunia. Sebagai pemuda Indonesia harus bangga akan apa yang negeri dimiliki.

Salah satu budaya Indonesia yang masuk dalam jajaran bahasa internasional adalah bahasa jawa. Untuk berkomunikasi sehari-hari, penduduk pulau Jawa mayoritas menggunakan bahasa jawa lokal baik dengan orang tua, muda, maupun pendatang. Sehingga tidak sedikit pendatang mancanegara belajar bahasa jawa agar dapat berkomunikasi dengan warga setempat. Sudah ada beberapa Universitas Luar Negeri yang menjadikan Satra Jawa menjadi salah satu mata kuliah. Tidak hanya itu, Universitas di Amerika Joke memiliki kelas sanggar jawa sebagai tempat pengkajian budaya jawa mulai dari nyinden, primary gamelan sampai tari jawa.

Beranekaragam kebudayaan yang dimiliki oleh Indonesia menjadi kebanggaan tersendiri oleh setiap warga Indonesia dan bangsa-bangsa di penjuru dunia. Dengan demikian tugas besar untuk para pemuda dan rakyat Indonesia harus ikut merawat, menjaga, mempertahankan, dan melestarikan budaya lokal agar tidak hilang maupun diakui oleh negara lain. Dengan melestarikan budaya lokal maka bangsa Indonesia sudah mampu menjaga budaya bangsa dari pengaruh budaya asing. Seperti contoh Bahasa Lampung yang hampir punah karena sudah jarang digunakan dalam kehidupan sehari-hari.

Banyak hal yang menyebabkan budaya lokal mulai dilupakan oleh generasi periode saat ini, salah satunya adalah masuknya budaya asing di tengah budaya lokal. Berdasarkan fakta yang terjadi, tidak sedikit generasi muda Indonesia lebih memilih kebudayaan asing karena menurut mereka kebudayaan asing lebih unik dan lebih menarik. Tidak sedikit kebudayaan lokal yang sudah luntur karena tidak adanya generasi penerus yang mewarisinya. Sudah menjadi kewajiban generasi muda penerus bangsa untuk menumbuhkan kesadaran pada diri masing-masing dan tiap-tiap masyarakat negeri Indonesia akan pentingnya merawat, menjaga, dan melestarikan kebudayaan lokal yang dimilliki oleh bangsa Indonesia serta meningkatkan rasa kebangsaan dan nasionalisme pasa tiaptiap penduduk negeri Indonesia. 


\section{Kesenian Sebagai Media Komunikasi Budaya}

Kesenian berasal dari kata dasar seni. Seni berarti keahlian membuat karya yang bermutu, karya yang diciptakan dengan keahlian yang luar biasa, seperti tari, lukisan ukiran. Kesenian mengacu pada nilai keindahan (estetika) yang berasal dari eskpresi hasrat manusia akan keindahan. ${ }^{14}$ Kesenian merupakan sarana yang digunakan untuk mengekspresikan keindahan dan berasal dari dalam jiwa manusia. Selain itu Kesenian juga merupakan media Komunikasi bagi masyarakat dan lingkungannya atau dengan kelompok masyarakat lainnya. ${ }^{15}$ Kesenian sebagai unsur kebudayaan terdiri berbagai cabang seni, salah satu diantaranya adalah tari. Tari mempunyai wujud yang berkaitan dengan perasaan, yang bersifat menggembirakan, mengharukan, atau mungkin mengecewakan. Dikatakan menggembirakan dan mengharukan karena tarian dapat menyentuh perasaan seseorang menjadi gembira setelah menikmati pertunjukan dengan puas. Tari dalam budaya atau masyarakat tertentu merupakan realisasi atau perujudan dari ekspresi kehidupan masyarakat. ${ }^{16}$

Dalam proses komunikasi budaya, media merupakan saluran yang dilalui oleh pesan atau simbol. Ada dua tipe saluran yang disepakati para ilmuwan sosial, yaitu sensory channel, yakni saluran yang

14 Benny Kurniawan, Ilmu Budaya Dasar, (Tangerang Selatan: Jelajah Nusa, 2012), 34.

${ }^{15}$ Sumaryono, Antropologi Tari (Yogyakarta: Akademi Seni Indonesia, 2011), 26.

16 Desfiarni, Tari Lukah Gilo, (Yogyakarta: Kalika, 2004), 1. memindahkan pesan, sehingga akan ditangkap oleh lima indera manusia, yaitu cahaya, bunyi tangan, hidung dan lidah. ${ }^{17}$ Media komunikasi merupakan seluruh sarana yang digunakan untuk memproduksi, mereproduksi, mendistribusi, dan menyampaikan informasi. Di zaman yang serba modern seperti sekarang ini, media dan komunikasi tidak lagi bisa dipisahkan. Media komunikasi memegang peran besar salam kehidupan masyarakat. Tanpa media, masyarakat kini akan kesulitan dalam melakukan proses komunikasi.

Media komunikasi juga menjadi sangat dibutuhkan dalam kehidupan bermasyarakat dikarenakan oleh fungsinya yang sangat membantu proses komunikasi menjadi lebih baik. Dengan adanya media komunikasi, memberikan kemudahan pada penyampaian informasi menjadi lebih baik. Dengan adanya media komunikasi, memberikan kemudahan pada penyampaian informasi menjadi menjadi lebih efektif dan efisien. Selain itu, dengan menggunakan media komunikasi, bisa mempercepat isi pesan yang bersifat abstrak (konkrit). Bahkan media komunikasi juga memiliki fungsi motivatif yang membuat para komunikator dan komunikan lebih semangat dalam melangsungkan proses komunikasi.

Kesenian di Indonesia berasal dari suatu tempat dimana ia tumbuh dalam lingkungan yang berbeda satu sama

17 Aang Ridwan, Komunikasi Antar Budaya mengubah Persepsi dan Sikap dalam Meningkatkan Kehidupan Manusia, (Bandung: CV Pustaka Setia, 2016), 106. 
lainnya. Kesenian berkembang dikalangan masyarakat yaitu berakar dan bersumber dari tradisi masyarakat lingkungannya. Seni dihasilkan oleh kreatifitas suatu suku di berbagai wilayah di Indonesia, sehingga seni bersifat kedaerahan. Peristiwa adat istiadat merupakan landasan utama bagi pelaksanaan seni pertunjukan. Seni pertunjukan terutama seni tari dengan diiringi bunyi-bunyian merupakan pengemban dari kekuatan magis yang diharapkan hadir. Kesenian khususnya seni pertunjukan memiliki beberapa fumgsi, yang pertama seni berfungsi untuk keperluan upacara, Pemanggilan kekuatan ghaib, pelengkapan upacara merupakan perwujudan dari dorongan untuk mengungkapkan keindahan. Kedua, Seni berfungsi sebagai media ekspresi. Seni merupakan media eskpresi untuk para seniman di trengah masyarakat dan menjadi kehidupan sehari-hari. Disamping menjadi kreator dia juga bisa berpartisipasi dalam perkembangan kesenian. Sehingga kesenian bisa menjadi bagian dari kegiatan rutinitas sekaligus hiburan.

Fungsi selanjutnya yaitu Seni sebagai sarana hiburan. Kesenian yang memiliki fungsi utama sebagai sarana upacara kini sudah bergeser fungsi yakni sebagai sarana hiburan yang memuat nilai-nilai moral didalamnya dan berkembang di lingkungan masyarakat tradusional. Selain sebagai sarana hiburan seni juga memiliki fungsi sebagai sarana pendidikan. Pada dasarnya, kesenian sebagai media pendidikan untuk menemukan nilai-nilai luhur yang terkandung melalui simbol-simbol pada pertunjukan. Muatan pendidikan yang bersifat moralitas dan pesan-pesan mudah diterima oleh masyarakat tradisional, hal ini terjadi karena keakraban cerita pada audio penonton.

\section{Metode Penelitian}

Dalam penelitian ini pendekatan yang dilakukan adalah melalui pendekatan deskriptif kualitatif. Pendekatan ini dipilih untuk mendapatkan data kualitatif yang objektif dan mendalam yang nantinya data hasil penelitian tersebut dapat disajikan secara deskriptif sehingga temuan hasil penelitian tersaji secara urut, detail dan mendalam. Deskriptif kualitatif digunakan peneliti untuk mendeskripsikan atau mengkonstruksi wawancara-wawancara mendalam terhadap subjek penelitian.

Subyek dalam penelitian ini adalah para pemain kesenian Tari Keling dan beberapa masyarakat Dusun Mojo Ds Singgahan Kec Pulung Kab Ponorogo yang mengetahui lebih dalam tentang kesenian tari keling. Jadi peneliti berupaya selalu mengikuti pementasan kesenian tari keling. Obyek adalah apa yang akan di selidiki dalam kegiatan penelitian. Beberapa persoalan sekiranya perlu peneliti pahami agar bias menentukan dan menyusun objek penelitian dalam metode penelitian dengan baik, yaitu berkaitan dengan apa itu obyek penelitian kualitatif, dan apa saja yang layak dijadikan obyek penelitian. Adapun obyek dalam penelitian ini adalah keilmuan komunikasi yang terkait dengan Komunikasi Budaya. 
Hasil dan Pembahasan

\section{Chandra, Tembang, dan Nyanyian Keling Sebagai Alat Pemersatu}

Kesenian keling Guno Joyo merupakan kesenian rakyat tradisional yang memiliki karakter yang khas. Perwujudan seni ini merupakan ekspresi masyarakat Dusun Mojo Desa Singgahan Kecamatan Pulung Kabupaten Ponorogo. Dalam mengungkapkan ide dan tujuan, masyarakat menggunakan berbagai media. Berbagai media tersebut menyatu dalam kesatuan, diantaranya yaitu chandra, tembang, dan nyanyian.

Chandra yang dibacakan oleh wiraswara sebelum pementasan seni keling mengandung suatu pesan yang disampaikan kepada penonton, yakni sebuah cerita asal mula kesenian keling yang diangkat dari cerita awal mula babat tanah Jawa. Menurut seniman keling, para penonton dan masyarakat perlu tahu asal mula kesenian yang mereka saksikan.

Fungsi komunikasi dalam kesenian keling adalah untuk memberikan pendidikan dan moral kepada setiap masyarakat. Dengan adanya kesenian keling berbagai nilai-nilai pendidikan dan moral yang mencakup norma agama, etika atau sopan santun, penampilan diri, estetika, bertingkah laku baik, saling menghargai satu sama lain, hidup dalam kepentingan individu dan kelompok, penempatan diri dalam masyarakat dan lain-lain. Salah satu unsur kesenian tari keling yang memberikan pesan yang berisi pendidikan moral adalah tembang
Dhandhang Gula Kesenian Keling yang dinyanyikan pada saat akan mulai pementasan. Berikut adalah tembang dhandhanggula:

Pada nyanyian Keling berisi tentang ajakan kepada masyarakat untuk segera hadir menyaksikan pemetasan kesenian tari keling yang indah dan bagus. Selain itu pada lagu diatas juga menyampaikan suatu pesan kepada masyarakat agar senantiasa rukun dan selalu bergotong royong, saling tolong menolong antar sesama manusia, khususnya masyarakat dukuh Mojo dan para penonton kesenian tari keling. Para seniman berharap bisa menampilkan yang terbaik sehingga bisa menghibur penonton dan dapat bermanfaat untuk masyarakat.

Lagu yang dinyanyikan selanjutnya adalah nyanyian keling yang dinyanyikan ketika penari putri sedang tampil. Terdapat beberapa pesan yang disampaikan seniman kepada para pecinta seni melalui nyanyian tersebut. Nyanyian ini berisikan tentang pemberitahuan kepada masyarakat bahwa Seni Keling itu bukan kesenian biasa, namun memiliki sejarah dan asal usul yang jelas.

Kesenian keling merupakan kesenian yang tidak bisa dianggap remeh dan tidak kalah dengan budayabudaya lain yang ada di Indonesia. Selain itu ada pesan lain yang dapat diambil dari nyanyian keling diatas. Bahwa dalam kesenian ini harus rukun dalam bernari bersenggolan sederhana tanpa adanya pertengkaran sesama seniman keling. 


\section{Alat Musik Pengiring Tari (Gamelan) Sebagai Identitas}

Alat musik tradisional seperti gamelan dalam perkembangannya di kancah internasional diperkenalkan oleh seniman gamelan dan minat warga asing yang ingin mempelajari musik gamelan sebagai alternatif musik orkestra. Tabuhan dan pukulan yang dihasilkan oleh instrumen musik gamelan menimbulkan suasana yang indah dan menenangkan, digunakan sebagai sarana relaksasi.

Musik gamelan memiliki keunikan yang beragam dalam perkembangannya sebagai ajang ekspresi di setiap daerah Indonesia yang menggunakannya. Alat musik gamelan memiliki fungsi penting yaitu sebagai upacara adat, hiburan, pendidikan dan kesehatan rohaniah. Dalam kesenian keling, alat musik gamelan berfungsi sebagai hiburan dan pendidikan, karena merupakan musik pengiring tari yang dijadikan sebagai kesenian, selain itu juga berfungsi sebagai pendidikan karena ada pesan moral yang disampaikan kesenian keling melalui alat musik gamelan. Permainan musik gamelan yang harus dimainkan secara bersama-sama memiliki arti gotong royong dalam tradisi Jawa, ia harus dimainkan secara selaras supaya menghasilkan irama yang indah. Sarana pendidikan adalah salah satu fungsi dari gamelan yakni sebagai ungkapan untuk mengekspresikan diri dengan karya dan mempelajari instrumen gamelan yang beragam. Musik gamelan juga bisa berfungsi sebagai sarana terapi bagi manusia dengan gangguan mental atau stres karena dapat menenagkan pikiran ketika mendengar alunan musiknya. Kekaguman warga asing terhadap musik gamelan didukung oleh rasa kebersamaan yang tercipta antara para pemain gamelan.

Selain itu, alat-alat musik atau gamelan dalam kesenian keling juga mengkomunikasikan berbagai aspek budaya. Alat-alat musik gamelan yang dimainkan dalam kesenian tradisional biasanya mengkomunikasikan suatu identitas masyarakat Indonesia khususnya jawa kuno. Gamelan sendiri muncul pertama kali yaitu pada zaman Wali Songo, yaitu sembilan wali penyebar agama Islam dan gamelan digunakan sebagai media untuk berdakwah. Oleh karena itu gamelan ini merupakan simbol dari budaya Islam yang didukung oleh budaya Indonesia, salah satunya yang digunakan sebagai pengiring kesenian tari Keling tersebut.

\section{Komunikasi Budaya Disampaikan Dalam Bentuk Verbal dan Nonverbal}

Komunikasi dalam kesenian tari keling Guno Joyo dilakukan melalui dua cara: yaitu komunikasi verbal (lisan) dan komunikasi nonverbal (bukan lisan). Yang termasuk ke dalam komunikasi verbal mencakup chandra, tembang dhandhanggula dan nyanyian keling. Dan yang termasuk komunikasi nonverbal adalah alat musik tradisional atau gamelan yang mengiringi tari. Alat musik gamelan dalam kesenian tari keling ini juga mengkomunikasikan berbagai aspek budaya. Alat musik ini 
biasanya mengkomunikasikan identitas masyarakat Indonesia khususnya orang jawa kuno. sedangkan gamelan sendiri pertama kali muncul pada zaman wali songo menyebarkan agama islam dan digunakan sebagai media dakwah. Maka dari itu gamelan ini adalah simbol dari budaya Islam yang salah satunya didukung oleh budaya di Indonesia.

Kesenian tari keling merupakan kesenian tari tradisional yang mewujudkan sarana komunikasi rakyat melalui berbagai bentuk dan cara berkomunikasi. Dalam hal ini komunikasi yang digunakan para pemain kesenian tari keling dalam proses pementasan adalah alunan musik gamelan yang mengiringi jalannya pementasan keling, nyanyian dan tembang yang ada dalam kesenian keling, bahasa yang digunakan adalah bahasa sehari-masyarakat yakni bahasa jawa, jadi kemungkinan besar sangat mudah untuk dipahami. Dalam pementasan kesenian tari keling, pesan yang disampaikan oleh para pemain melalui suara dan gamelan.

\section{Kesimpulan}

Dalam kesenian ini menyampaikan beberapa pesan yang memiliki unsur budaya yang disebut dengan komunikasi budaya. Komunikasi budaya yang disampaikan dalam kesenian keling terbagi dalam dua bentuk. Yaitu verbal dan nonverbal. Komunikasi verbal adalah komunikasi yang disampaikan secara langsung atau lisan, yakni melalui candra, tembang dhandhanggula, dan nyanyian keling. Sedangkan komunikasi nonverbal adalah komunikasi non lisan dan sebagai pendukung komunikasi verbal. Komunikasi nonverbal dalam hal ini meliputi alat musik tradisional atau gamelan. Alat musik atau gamelan itu sendiri mengkomunikasikan berbagai aspek budaya dan suatu identitas masyarakat Indonesia khususnya Jawa.

\section{Daftar Pustaka}

Arif, Moh Choirul. Dasar-dasar Kajian Budaya dan Media. Sidoarjo: UIN Sunan Ampel Press, 2014.

Barker, Larry L. Communication, ed. 3. Englewood Cliffs: Prentice-Hall, 1994.

Bustomi, Suwaji. Seni Dan Budaya Jawa. Semarang: IKIP Semarang Press, 1992.

Data Monografi desa Singgahan, kecamatan Pulung, kabupaten Ponorogo, 2013.

Desfirni. Tari Lukah Gilo. Yogyakarta: Kalika, 2004.

Gumilar, Setya \& Sulaiman. Teori-Teori Kebudayaan. Bandung: Pustaka Setya, 2013.

Hartoko, Dick. Manusia dan Seni. Yogyakarta: Kanisius, 1984).

Jahi, Amri. Komunikasi Massa dan Pembangunan Pedesaan di Negara ke Tiga: Suatu Pengantar. Jakarta: Gramedia, 1983.

Kabupaten Ponorogo. Dokumentasi Statistik Kabupaten Ponorogo. 2012.

Karsono, Saputra. Pengantar Sekar Macapat. Depok: Fakultas Sastra Universitas Indonesia, 1992. 
Koentjaningrat. Pengantar Ilmu Antropologi. Jakarta: Aksara Baru, 1985.

Kurniawan, Benny. Ilmu Budaya Dasar. Tangerang Selatan: Jelajah Nusa, 2012.

Maulana, Agus. Komunikasi Antar

Manusia. Jakarta: Profesional Books, 1997.

Meoleong. Lexi J. Metode Penelitian Kualitatif. Bandung: PT. Remaja Rosdakarya, 2007.

Moeliono, Anton M. Kamus Besar Bahasa Indonesia Jakarta: Balai Pustaka, 1990.

Mulyana, Deddy dan Jalaluddin Rakhmat. Komunikasi Antar Budaya. Bandung: Remaja Rosdakarya, 1993.

Mulyana, Deddy. Metodologi Penelitian Kualitatif, Paradigma Baru Ilmu Komunikasi Dan Ilmu Sosial Lainnya. Bandung: PT Remaja Rosdakarya, 2008.

Narullah, Rulli. Komunikasi Antarbudaya: Di Era Budaya Siberia. Jakarta: Kencana, 2014.

Nurdin, Ali. Pengantar Ilmu Komunikasi. Surabaya: IAIN Sunan Ampel Press, 2014.

Pawito. Penelitian Komunikasi Kualitatif. Yogyakarta: LKIS Pelangi Aksar, 2008.

Pujiksono, Sugeng. Metode Penelitian Kualitatif. Malang: Kelompok Intrans Publishing, 2015.

Rakhmat, Jalaludin. Psikologi Komunikasi. Bandung: PT Rosda Karya, 2005.
Ridwan, Aang. Komunikasi Antar Budaya Mengubah Persepsi dan Sikap dalam Meningkatkan Kehidupan manusia. Bandung: Pustaka Setia, 2016.

Ritzer, George. Teori Sosiologi Dari Sosiologi Klasik Samai Sampai Perkembangan Terakhir Postmodern. Yogyakarta: Pustaka Belajar, 2012.

Rizer, George. Sosiologi Ilmu Berparadigma Ganda. Jakarta: CV. Rajawali, 2011.

Sadily, Hasan. Ensiklopedia Indonesia. Jakarta: PT.Ictiar Baru-Van Hoeve, 1943.

Sihabudin, Ahmad. Komunikasi Antar Budaya: Satu Perspektif Multidimensi. Jakarta: PT Bumi Aksara, 2011.

Sugiyono. Metode Penelitian Kuantitatif dan Kualitatif dan $R \& D$. Bandung: Alfabeta, 2012.

Tanjung, Anita Chairul. Pesona Indonesia. Jakarta: Gramedia Pustaka, 2006. 